\title{
Roles of CHOP/GADD153 in endoplasmic reticulum stress
}

\author{
S Oyadomari ${ }^{*, 1,2}$ and M Mori ${ }^{\star, 1}$ \\ ${ }^{1}$ Department of Molecular Genetics, Graduate School of Medical Sciences, \\ Kumamoto University, Kumamoto 860-8556, Japan \\ 2 Current address: Skirball Institute of Biomolecular Medicine, New York \\ University School of Medicine, 540 First Avenue, New York, NY 10016, USA \\ * Correspondence: S Oyadomari or M Mori, Department of Molecular Genetics, \\ Graduate School of Medical Sciences, Kumamoto University, Honjo 1-1-1, \\ Kumamoto 860-8556, Japan; Tel: + 8196373 5140; Fax: + 81963735145 \\ E-mails: oyadomar@saturn.med.nyu.edu or masa@gpo.kumamoto-u.ac.jp
}

Received 16.7.03; revised 03.11.03; accepted 04.11.03; published online 19.12 .03 Edited by M Piacentini

\begin{abstract}
Endoplasmic reticulum (ER) is the site of synthesis and folding of secretory proteins. Perturbations of ER homeostasis affect protein folding and cause ER stress. ER can sense the stress and respond to it through translational attenuation, upregulation of the genes for ER chaperones and related proteins, and degradation of unfolded proteins by a quality-control system. However, when the ER function is severely impaired, the organelle elicits apoptotic signals. ER stress has been implicated in a variety of common diseases such as diabetes, ischemia and neurodegenerative disorders. One of the components of the ER stress-mediated apoptosis pathway is C/EBP homologous protein (CHOP), also known as growth arrestand DNA damage-inducible gene 153 (GADD153). Here, we summarize the current understanding of the roles of CHOP/ GADD153 in ER stress-mediated apoptosis and in diseases including diabetes, brain ischemia and neurodegenerative disease.

Cell Death and Differentiation (2004) 11, 381-389. doi:10.1038/

sj.cdd. 4401373

Published online 19 December 2003
\end{abstract}

Keywords: endoplasmic reticulum; transcription factor; apoptosis; pancreatic cells; diabetes; nitric oxide

\footnotetext{
Abbreviations: AARE, amino-acid-regulatory element; ATF, activating transcription factor; CHOP, C/EBP homologous protein; DOCs, downstream of $\mathrm{CHOP}$; elF2 $\alpha$, eukaryotic initiation factor $\alpha$; ER, endoplasmic reticulum; ERAD, ER-associated degradation; ERSE, ER stress response element; GADD153, growth arrest- and DNA damage-inducible gene 153; PERK, PKR-like ER kinase; SERCA, sarcoplasmic ER $\mathrm{Ca}^{2+}$-ATPase; UPRE, unfolded protein response element; XBP-1, $x$-box-binding protein-1
}

\section{Endoplasmic Reticulum (ER) Stress and CHOP}

Proteins must be folded into proper conformations, in order to carry out their cellular functions. Unfolded or misfolded proteins are harmful to cells in that cell survival can be threatened. ${ }^{1}$ ER is the site of synthesis and folding of proteins destined for secretion, cell membrane, Golgi apparatus, lysosomes and others. However, protein folding in the ER is impaired under various physiological and pathological conditions, collectively called 'ER stress'. ${ }^{2}$ In order to overcome ER stress, this organelle has a specific signaling pathway termed the ER stress response pathway, which involves at least four responses (Figure 1). ${ }^{3-5}$ The first response is translational attenuation, reducing the load of new protein synthesis and preventing further accumulation of unfolded proteins. ${ }^{6}$ The second response is upregulation of genes encoding ER chaperone proteins such as BiP/GRP78 and GRP94, enzymes including protein disulfide isomerase (PDI) and peptidyl-prolyl isomerase, and structural components of the ER including sarcoplasmic ER $\mathrm{Ca}^{2+}$-ATPase 2 (SERCA2), to increase the protein-folding capacity in ER. ${ }^{7-9}$ In addition to these genes, recent studies revealed that genes involved in translational recovery, amino-acid import, glutathione biosynthesis and protection against oxidative stress are also upregulated. ${ }^{10}$ In a later phase, components of ER-associated degradation (ERAD), including ER degradation-enhancing $\alpha$-mannosidase-like protein (EDEM), are transcriptionally induced to eliminate misfolded proteins in the ER by the ubiquitin-proteasome system. ${ }^{11-13}$ The third involves activation of $\mathrm{NF} \kappa \mathrm{B}$, a transcription factor known as a mediator of immune and antiapoptotic responses. ${ }^{14}$ This pathway is designated ER overload response (EOR), because it is triggered by accumulation of membrane proteins in the ER. It is believed that the stress leads to $\mathrm{Ca}^{2+}$ release from ER and sequent production of reactive oxygen intermediates, which activate $\mathrm{NF} \kappa \mathrm{B}$ by degradation of $I_{\kappa} \mathrm{B}$. However, it is not known how the $\mathrm{Ca}^{2+}$ permeability is induced in signaling EOR. A recent finding that the elF2 $\alpha$ phosphorylation is required for induction of $\mathrm{NF} \kappa \mathrm{B}$ suggests that the stresstransducing molecule for EOR is shared with other ER stressinduced transcriptional program. ${ }^{15}$ The fourth is apoptosis, which occurs when functions of the ER are severely impaired, to protect the organism by eliminating the damaged cells. ${ }^{16,17}$ At least three apoptosis pathways are known to be involved in this apoptotic event. The first is transcriptional activation of the gene for C/EBP homologous protein (CHOP). The second is activation of the cJUN NH2-terminal kinase (JNK) pathway, which is mediated by formation of the inositol requiring 1 (Ire1)-TNF receptor-associated factor 2 (TRAF2)-apoptosis signal-regulating kinase1 (ASK1)' complex. ${ }^{18,19}$ The third is activation of ER-associated caspase-12 (see Yuan, this 
review series). Caspase-12 is activated by ER stress, but apparently not by death receptor-mediated or mitochondriatargeted apoptotic signals. ${ }^{20}$ Although caspase- 12 serves as a marker of ER stress-induced apoptosis in mouse, humans lack functional caspase-12 homologue because of acquiring multiple stop codons. ${ }^{21}$ Therefore, all the three apoptosis pathways eventually lead to the activation of caspase-3, suggesting that ER stress signals are finally transmitted to the mitochondria. In addition, mouse embryo fibroblasts from $\mathrm{Bax}^{-1-} \mathrm{Bak}^{-1-}$ mice are resistant to apoptosis induced by ER stress, suggesting the role of Bax and Bak as executioners in ER stress-mediated apoptosis. ${ }^{22}$ Furthermore, overexpression of Bcl-2 blocks CHOP-induced apoptosis. ${ }^{23}$ Therefore, mitochondria function as an integrator and amplifier of this death pathway. Here, we summarize the recent findings on the roles of CHOP in ER stress-mediated apoptosis.

\section{Structure and Properties of CHOP}

CHOP is a $29 \mathrm{kDa}$ protein with 169 (human) or 168 (rodents) amino-acid residues. CHOP protein was first identified to be a member of the CCAAT/enhancer binding proteins (C/EBPs) that serves as a dominant negative inhibitor of C/EBPs. ${ }^{24}$ $\mathrm{CHOP}$ is also known as growth arrest- and DNA damageinducible gene 153 (GADD153), DNA-damage-inducible transcript 3 (DDIT3) and $\mathrm{C} / \mathrm{EBP} \zeta$. The GADD genes are a group of genes that are induced by genotoxic stress and growth arrest signals. There are three distinct GADD genes, GADD34, GADD45 and GADD153, but there is no similarity among them. C/EBPs form a family of transcription factors that regulate a variety of genes involved in a broad range of physiological processes, including immune functions as well as cell differentiation and proliferation. To date, six distinct members of the C/EBP family have been identified. CHOP protein is composed of two known functional domains, an $\mathrm{N}$ terminal transcriptional activation domain and a C-terminal basic-leucine zipper (bZIP) domain consisting of a basic amino-acid-rich DNA-binding region followed by a leucine zipper dimerization motif (Figure 2). ${ }^{24,25}$ Furthermore, CHOP protein contains two adjacent serine residues (79 and 82 ) that can serve as substrates of the p38 MAP kinase family. ${ }^{26}$ Deletion mutant analysis of CHOP revealed that bZIP domain is important for CHOP-induced apoptosis. ${ }^{23,27}$ The high conservation $(>90 \%$ ) in the bZIP domain of the C/EBP members allows for formation of homodimers and heterodimers of the members. CHOP is a heterodimer with other $\mathrm{C} /$ EBPs that strongly prefer to homodimerize. ${ }^{24,28}$ However, $\mathrm{CHOP}$ contains proline and glycine substitutions in the basic region that disrupt its DNA-binding activity. Consequently, CHOP-C/EBP heterodimers cannot bind to a C/EBP site $5^{\prime}$ (A/G)TTGCG(C/T)AA(C/T)-3'. On the other hand, CHOP-C/ EBP heterodimers can bind to another unique site $5^{\prime}-(A / G)(A /$ G) (A/G)TGCAAT(A/C)CCC-3' to activate target genes. ${ }^{25}$ Furthermore, CHOP can enhance the transcriptional activation of AP-1 by tethering to the AP-1 complex without direct binding of DNA. ${ }^{29}$ Thus, CHOP has a dual role both as an inhibitor of C/EBPs function and as an activator of other genes.

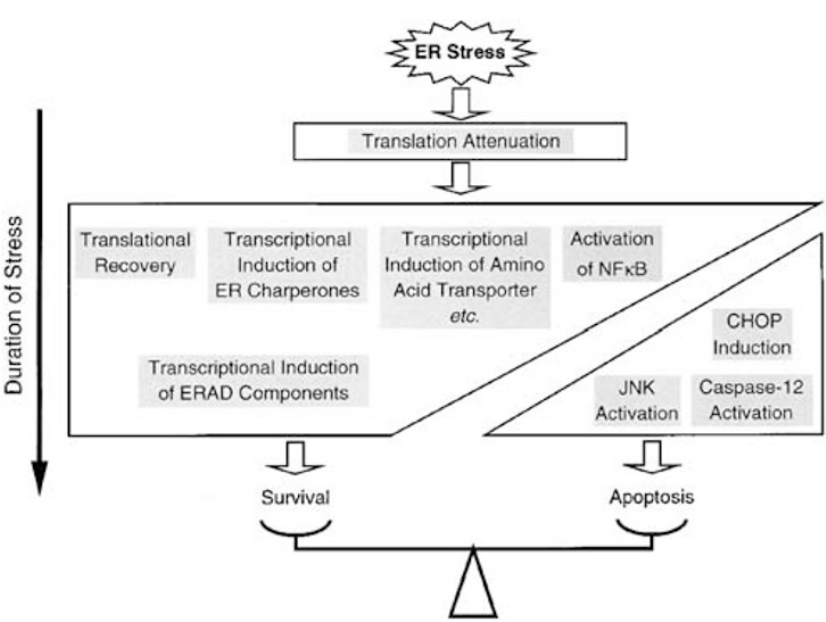

Figure 1 Proposed profile of ER stress response. In an early phase, translational attenuation occurs to reduce the load of ER. In the next phase, several groups of genes are transcriptionally induced for long-term adaptation to ER stress. New synthesis of stress-induced proteins escapes from the general translational attenuation. To cope with the unfolded proteins in the ER, ER chaperones are first induced to refold them and if this response is not enough, ERAD components are then induced to eliminate the unfolded proteins. To remodel the ER, variety of genes such as those of amino-acid import, glutathione biosynthesis, and oxidation protection are also induced. To elicit immune response and antiapoptotic effect, $\mathrm{NF}_{\kappa} \mathrm{B}$ is activated. On the other hand, if severe ER stress conditions persist, the apoptosis signaling pathways are activated, including induction of CHOP and activation of JNK kinase and caspase-12. The decision between survival or apoptosis may depend on the balance between survival signaling and apoptosis signaling

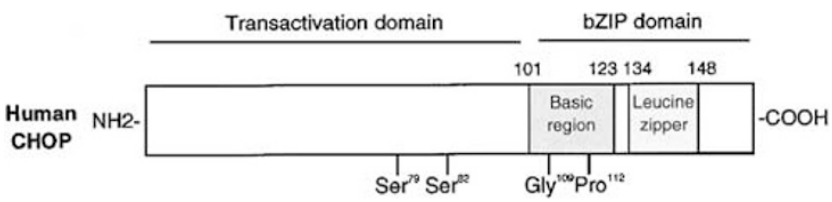

Figure 2 Domain structure of human CHOP. CHOP is composed of its $\mathrm{N}$ terminal putative transactivation domain and a C-terminal bZIP domain that contains a DNA-binding basic region and a leucine zipper dimerization region. The basic region contains conserved glycine (109) and proline (112) residues, which are essential for binding to the consensus C/EBP-binding site. Two serine residues (79 and 82 ) in the transactivation domain are phosphorylated by p38 MAP kinase, and this phosphorylation is required for the enhanced transcriptional activation

\section{Expression Profile of CHOP}

CHOP is ubiquitously expressed at very low levels. ${ }^{24} \mathrm{How}$ ever, it is robustly expressed by perturbations that induce stress in a wide variety of cells. ${ }^{24} \mathrm{CHOP}$ is present in the cytosol under nonstressed conditions, and stress leads to induction of CHOP and its accumulation in the nucleus. ${ }^{24}$ The CHOP gene was initially identified in a search for genes induced by genotoxic stress such as UV irradiation and alkylating agents methyl methanesulfonate (MMS), and was thus named GADD153. ${ }^{30} \mathrm{CHOP}$ was also noted to be induced by nutrient depletion such as glucose deprivation and aminoacid starvation. Subsequent studies revealed that a DNAdamaging nucleoside analogue or UV light alone does not induce CHOP. ${ }^{31}$ Glucose deprivation is known to induce ER stress, presumably by inhibiting $\mathrm{N}$-linked protein glycosylation 
in the ER. Other strong inducers of CHOP, such as tunicamycin which blocks protein glycosylation, thapsigargin which promotes ER stress by depletion of ER calcium stores and dithiothreitol which disrupts disulfide bond formation, strongly perturb ER functions. MMS may affect ER protein folding by alkylating cysteine residues of ER proteins rather than by damaging DNA. All these findings suggest that induction of $\mathrm{CHOP}$ is more responsive to ER stress than is DNA damage.

\section{Transcriptional Regulation of CHOP}

Expression of $\mathrm{CHOP}$ is mainly regulated at the transcriptional level. Recent microarray studies revealed that $\mathrm{CHOP}$ is one of highest inducible genes during ER stress. ${ }^{32}$ ER stress response consists of the transcriptional upregulation program, which is conducted by three distinct types of ER stress transducers localized on the ER membrane, PKR-like endoplasmic reticulum kinase (PERK), activating transcription factor $6 \alpha$ (ATF6 $\alpha$ and ATF6 $\beta)$ and Ire1 $\beta$ and Ire1 $\beta$. Three transcription factors, ATF4, pATF $6 \beta(\mathrm{N})$ and pATF $6 \beta(\mathrm{N})$, and $\mathrm{x}$-box binding protein-1 (XBP-1), were identified to be downstream effectors of these signaling pathways. BiP works as a sensor of unfolded proteins in the ER and regulates the activation of these ER stress transducers. ${ }^{33,34}$ All transducers contain a lumenal domain to which $\mathrm{BiP}$ can bind. Under normal conditions, BiP binds to the lumenal domains of Ire $1 \alpha$, Ire $1 \beta$ and PERK, and prevents their homodimerization transport to the Golgi apparatus. Under ER stress conditions, $\mathrm{BiP}$ binds to unfolded proteins and thereby renders each transducer to activate. Activated PERK phosphorylates Ser51 on eukaryotic initiation factor- $2 \alpha($ elF2 $\alpha$ ) and blocks the binding of the initiator Met-tRNA to the ribosome by inhibiting the turnover of elF2B. As the frequency of the AUG initiation codon recognition is reduced, the general translation is attenuated. However, ATF4 mRNA is efficiently translated under these conditions because of its small upstream openreading frames (UORF) within the $5^{\prime}$ untranslated region, called 'uORF bypass scanning system'. ATF4 can bind both the consensus ATF/CRE element sequence 5'-TGACGTCA$3^{\prime}$ and the amino-acid-regulatory element (AARE) core sequence 5'-ATTGCATCA-3'. BiP-free pATF6 $\alpha(p)$ and pATF6 $\beta(\mathrm{p})$ are transported to the Golgi apparatus and cleaved by Site-1 protease and Site-2 protease. ${ }^{35}$ The released N-terminal cytosolic domain $(\mathrm{pATF} 6 \alpha(\mathrm{N})$ and pATF $6 \beta(N))$ are transported into the nucleus. pATF $6 \alpha(N)$ and $\operatorname{pATF} 6 \beta(\mathrm{N})$ contain a bZIP domain and bind to the ER stress response element (ERSE) consensus sequence $5^{\prime}$ CCAAT- $\mathrm{N}_{9}$-CCACG-3' as a homo- or heterodimer interacting with NF-Y trimer. ${ }^{36,37}$ Activated Ire $1 \alpha$ and Ire $1 \beta$ cleave the substrate precursor XBP-1 mRNA to mature XBP- 1 mRNA by their endoribonuclease activity present in their cytosolic domains. ${ }^{38-40}$ XBP-1 splicing removes a 26-nucleotide intron, which switches the open reading frames to yield its bZIP and transactivation domain. Only the spliced form of XBP-1 has potential transcription activity and can bind both the ERSE and the unfolded protein response element (UPRE) sequence $5^{\prime}$-TGACGTGG-3' in interaction with NF-Y. ${ }^{38,41}$ Furthermore, $\mathrm{XBP}-1 \mathrm{mRNA}$ is induced first by ATF6, and thereafter by XBP-
1 carrying the ERSE in its promoter, which can efficiently cope with ER stress by positive feedback. ${ }^{36,38}$

As shown in Figure 3, the human CHOP promoter contains at least two ERSE motifs and one AARE motif. Two ERSE (CHOP ERSE-1 and CHOP ERSE-2) are located in opposite directions with a 9 bp overlap. ${ }^{36,42}$ These sequences are highly homologous with other ERSEs identified in the promoters of the BiP, GRP94, PDI and calreticulin (CRT) genes. ${ }^{8,43} \mathrm{CHOP}$ AARE was identified to be an essential motif for amino-acid activation of the CHOP promoter. ${ }^{44}$ This sequence has weak homology with $\mathrm{C} / \mathrm{EBP}$ - and ATF-binding sites. ATF2 and ATF4 were shown to be involved in the amino-acid regulation of $\mathrm{CHOP}$. While overexpression of pATF $6 \alpha(\mathrm{N})$ induces the expression of $\mathrm{CHOP}$, the induction of ATF4 and CHOP by ER stress is nearly completely attenuated in PERK null cells and elF2 $\alpha^{\mathrm{S} 51 \mathrm{~A}}$ cells. These results suggest that the PERK/elF2 $\alpha$ signaling pathway plays an essential role in the induction of CHOP in ER stress, and is dominant over that of the ATF6 and Ire1/XBP-1 signaling pathways. ${ }^{45,46}$ However, in order to achieve maximal induction of $\mathrm{CHOP}$, the presence of all these signaling pathways is required. ${ }^{32}$ On leucine starvation, ATF2 was reported to play an essential role in the expression of CHOP, when ATF2 null cell lines and an ATF2 dominant-negative mutant were used. ${ }^{44}$ During arsenite-induced stress, ATF3 represses, while ATF4 activates, the expression of $\mathrm{CHOP}$ through time-dependent changes in the binding to the AARE. ${ }^{47-49}$ ATF2 and ATF3 were reported

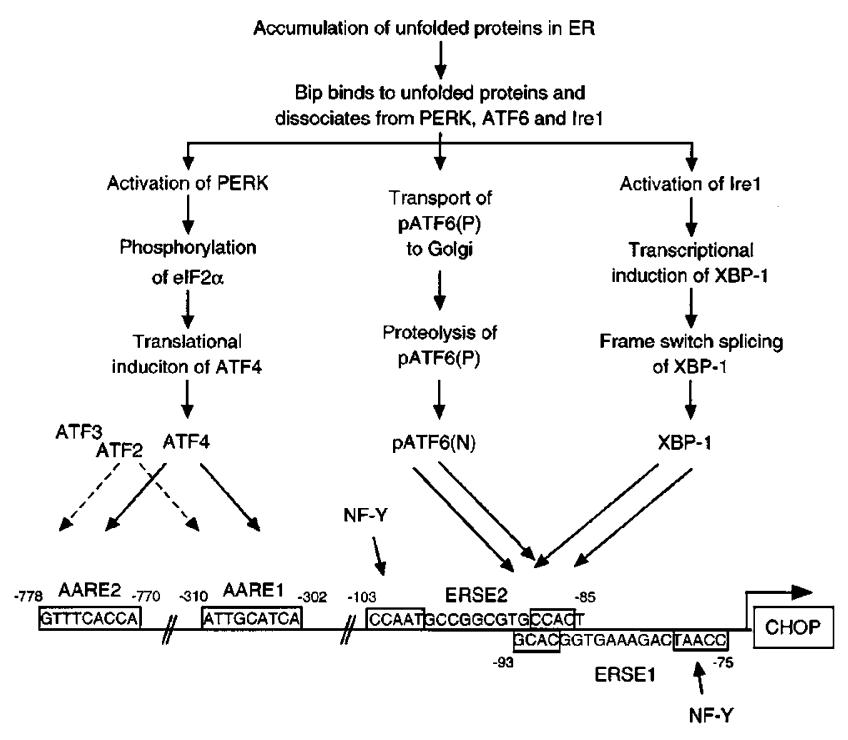

Figure 3 Mechanism of transcriptional induction of CHOP in ER stress. Under ER stress conditions, BiP binds to unfolded proteins and thereby renders each ER stress transducers including PERK, ATF6 and Ire1 to be activated. Activated PERK phosphorylates elF2 $\alpha$, which results in translational induction of ATF4. BiP-free pATF6(p) is transported to the Golgi apparatus and pATF6(N) is released by proteolysis. Activated Ire1 cleaves XBP-1 mRNA precursor to mature XBP-1 mRNA by unique splicing. XBP-1 mRNA precursor is also upregulated by pATF6(N). On ER stress, the transcriptional induction of CHOP is regulated at least by four cis-acting elements, AARE1, AARE2, ERSE1 and ERSE2. ATF4, pATF6 (N) and XBP-1 are known to activate transcription of CHOP. ATF4 binds to AARE1 and AARE2. ATF2 and ATF3 can bind to the CHOP AARE. However, the role of ATF2 and ATF3 in induction of CHOP during ER stress is unclear. Both pATF6(N) and XBP-1 bind to the CACG part of ERSE1 and ERSE2. NF-Y constitutively binds to the CCAAR part of ERSE1 and ERSE2 
to be induced under hypoxia, which induces ER stress. ${ }^{47,50}$ Therefore, they may also regulate the expression of $\mathrm{CHOP}$ in ER stress.

\section{Post-transcriptional Regulation of CHOP}

In addition to transcriptional regulation, the expression of CHOP is also regulated by mRNA stability. ${ }^{51,52}$. The $5^{\prime}$ untranslated region (5'UTR) of CHOP mRNA contains highly conserved uORF sequences among humans, mouse and hamster. ${ }^{53,54}$ This CHOP uORF, which is present between +1 and +170 in the human CHOP $5^{\prime}$ UTR, was shown to repress the translation of $\mathrm{CHOP} .{ }^{53,54}$ Under ER stress conditions, CHOP protein undergoes phosphorylation of Ser78 and Ser81 by the p38 MAP kinase family. ${ }^{26,27}$ Studies making use of the inhibition of p38 MAP kinase by SB20580, overexpression of p38 MAP kinase and mutation of phosphorylation sites indicate that the phosphorylation enhances transcriptional activation and elicits a maximal apoptotic effect of CHOP. ${ }^{23,26,27}$ MAPKKK ASK1, which is required for activation of JNK by Ire1 during ER stress, can also activate the p38 pathway. ${ }^{19,55}$ ASK1 null cells are resistant to ER stress-induced apoptosis. ${ }^{19}$ Therefore, it may be worthwhile to see if ASK1 is involved in the phosphorylation of CHOP in ER stress.

\section{Downstream of CHOP in ER Stress-induced Apoptosis}

Overexpression of CHOP and microinjection of CHOP protein have been reported to lead to cell cycle arrest and/or apoptosis. ${ }^{23,27,28,56,57}$. Overexpression of $\mathrm{BiP}$ attenuates the induction of CHOP in ER stress and reduces ER stressinduced apoptosis. ${ }^{31} \mathrm{CHOP}^{-/-}$mice exhibit reduced apoptosis in response to ER stress. ${ }^{56,58,59}$ Thus, CHOP plays an important role in ER stress-induced apoptosis. Concerning the downstream of CHOP in the apoptosis pathway, cells lacking CHOP's major dimerization partner C/EBP $\beta$ are also resistant to ER stress-induced apoptosis, suggesting that $\mathrm{CHOP}$ works as a transcriptional factor that regulates genes involved in either survival or death. ${ }^{58}$ Using representative difference analysis, Ron and colleagues found three target genes of CHOP that they referred to as DOCs (for downstream of CHOP). ${ }^{60,61}$ DOC1 is a stress-inducible form of carbonic anhydrase $\mathrm{VI}$, which is predicted to increase the proton concentration and to decrease intracellular $\mathrm{pH}$. DOC4 is a homologue of Tenm/Odz, which might function in signaling at compartment boundaries. DOC6 is a homologue of the actin-binding proteins villin and gelsolin, and is implicated in changes in the actin cytoskeleton during apoptosis. However, none is directly linked to either survival or death.

On the other hand, overexpression of CHOP leads to decrease in $\mathrm{Bcl}-2$ protein and overexpression of $\mathrm{Bcl}-2$ blocks CHOP-induced apoptosis. ${ }^{23,62}$ Splenic lymphocytes from $\mathrm{CHOP}^{-1-}$ mice are relatively resistant to LPS-induced apoptosis, which is associated with increased Bax and Bak mRNAs and decreased Bcl-2 mRNA (S Oyadomari et al., unpublished observation). Furthermore, overexpression of
$\mathrm{CHOP}$ leads to translocation of Bax protein from the cytosol to the mitochondria. ${ }^{62 a}$ Thus, CHOP-mediated death signal is finally transmitted to the mitochondria, which functions as an integrator and amplifier of the death pathway. It is to be noted that cells from $\mathrm{Bax}^{-1-} \mathrm{Bak}^{-1-}$ mice are resistant to apoptosis induced by ER stress; hence, Bax and Bak may function as executioners in ER stress-mediated apoptosis. ${ }^{22}$ Whether or not $\mathrm{CHOP}$ affects the $\mathrm{Bcl}-2$ protein family directly or indirectly is unknown.

Induction of $\mathrm{CHOP}$ was reported to perturb the cellular redox state by depletion of cellular glutathione. ${ }^{62}$ Cells lacking CHOP's dominant transactivator ATF4 were seen to affect antioxidative genes including those linked to glutathione synthesis and to amino-acid transport. ${ }^{10}$ Protein secretion results in the net loss of reducing equivalents by consuming cysteine to form disulfide bonds in the ER. In addition, ER stress is predicted to enhance both a loss of reduced glutathione and amino-acid insufficiency. Whether or not $\mathrm{CHOP}$ regulates antioxidative target genes downstream of ATF4 is being given attention.

It is also possible that CHOP-mediated apoptosis occurs through a nontranscriptional mechanism such as proteinprotein interactions. For example, $\mathrm{C} / \mathrm{EBP} \alpha$ was shown to elicit an antiproliferative effect by protein-protein interactions completely distinct from its role as a transcription factor. Namely, C/EBP $\alpha$ directly interacts with CDK2 and CDK4, and causes cell growth arrest by inactivating these kinases through proteasome-dependent degradation. ${ }^{63,64}$ In addition, Zip kinase, which mediates apoptosis, was identified as an ATF4-interacting protein. ${ }^{65}$ Therefore, search for an effector molecule of apoptosis which interacts with CHOP may be interesting. Thus, compared with the great progress in understanding the upstream of $\mathrm{CHOP}$ induction, the downstream of CHOP awaits further study.

\section{Role of CHOP-mediated Apoptosis in Normal Cell Growth and Differentiation}

Although $\mathrm{CHOP}^{-1-}$ cells are resistant to ER stress-mediated apoptosis, $\mathrm{CHOP}^{-1-}$ mice have a normal development and normal fertility, ${ }^{56,58}$ properties similar to those of caspase $12^{-1}$ - and $\mathrm{ASK} 1^{-1-}$ cells and mice. Thus CHOP is dispensable for organogenesis and development, probably because of redundancy of the apoptosis pathway. In contrast, the phenotype of $\mathrm{CHOP}^{-1-}$ mice differs markedly from those of Ire $1 \alpha^{-1-}, \mathrm{XBP}_{-1}{ }^{-1-}, \mathrm{PERK}^{-1-}$ and elF2 $\alpha^{\text {S51A }}$ knockin mice. ${ }^{18,40,45,66-68}$ Ire $1 \alpha^{-1-}$ and $\mathrm{XBP}^{-1} 1^{-1-}$ mice, which can induce ER chaperones upon ER stress, are embryonic lethal. ${ }^{18,40,66}$ XBP $-1^{-1-}$ livers show hypoplasia with numerous apoptotic hepatocytes, and $\mathrm{XBP}-1^{-1-} \mathrm{B}$ cells fail to differentiate to plasma cells. ${ }^{66,69} \mathrm{PERK}^{-1-}$ and elF $2 \alpha^{\text {S51A }}$ knockin mice have progressive pancreatic $\beta$-cell dysfunction due to increased apoptosis of the cells. ${ }^{45,67,68}$ It should be noted that cells from PERK ${ }^{-1-}$ and elF $2 \alpha^{\mathrm{S} 51 \mathrm{~A}}$ knockin mice are highly susceptible to ER stress; yet they are incapable of inducing CHOP upon ER stress. ${ }^{45,46,70}$ Therefore, ER stress occurs under physiological conditions and the ER stress response plays an essential role in cell growth and differentiation. However, the role of ER stress-mediated apoptosis in this 
process is not clear, because of the redundancy of the ER stress-mediated apoptosis pathway. Upregulation of $\mathrm{CHOP}$ was observed during certain stages of differentiation of $B$ cells, erythroids and keratinocytes. ${ }^{71,72}$ Under certain conditions, $\mathrm{CHOP}^{-1-}$ mice have splenomegaly at least partly due to reduced apoptosis of $\mathrm{B}$ cells (S Oyadomari, unpublished observation). One could examine the role of ER stressmediated apoptosis in development by generating double or triple knockout mice for the CHOP, caspase-12 and ASK1 genes.

\section{Role of CHOP-mediated Apoptosis in Disease}

Apoptosis plays an important role in maintaining tissue homeostasis. Accumulated evidence suggests that dysregulation of apoptosis is involved in the pathogenesis of a number of human diseases. Enhanced apoptosis may cause neurodegenerative disease, diabetes and acquired immune deficiency syndrome through cell loss. On the other hand, impaired apoptosis has been implicated in cancer and autoimmune disease. Here we briefly summarize what is known of the role of $\mathrm{CHOP}$ in the development of several diseases.

\section{Diabetes}

Diabetes is characterized by hyperglycemia due to reduced insulin secretion and impaired insulin action.. Excessive loss of $\beta$-cells is known to be a cause of diabetes, and apoptosis is the main mode of pancreatic $\beta$-cell death in the development of diabetes. ${ }^{73}$ One of the characteristic features of $\beta$-cells is a highly developed ER to secrete insulin. Ire $1 \alpha$ and PERK are expressed at high levels in pancreatic $\beta$-cells, probably reflecting a high participation of the cells in protein secretion. In mice genetically inactivated for the PERK-elF2 $\alpha$ pathway and in humans lacking PERK, revealed $\beta$-cells are the most susceptible to ER stress. ${ }^{17,74-76} \mathrm{PERK}^{-1-}$ mice develop progressive apoptosis in their $\beta$-cells and show marked hyperglycemia from 4 weeks of age. ${ }^{67,68}$ Mutations in the PERK gene were identified, in patients with Wolcott-Rallison syndrome, as an autosomal recessive disease with severe infant diabetes due to pancreatic hypoplasia and a reduced number of $\beta$-cells. ${ }^{77,78}$ elF $2 \alpha^{\mathrm{S} 51 \mathrm{~A}}$ knockin mice have more severe $\beta$-cell deficiency as seen in 16.5-18.5 embryos, and die within $18 \mathrm{~h}$ after birth due to hypoglycemia associated with defective gluconeogenesis. ${ }^{45}$ The different phenotype between $\mathrm{PERK}^{-1-}$ mice and elF2 $\alpha^{\mathrm{S} 51 \mathrm{~A}}$ knockin mice are probably due to partially redundant elF2 $\alpha$ kinases such as GCN2. Therefore, $\beta$-cells undergo ER stress even under physiological conditions and disturbance in the ER stress response leads to apoptosis.

Diabetes is classified into two types according to the etiological process. Type I diabetes is characterized by islet cell destruction mainly due to autoimmune and inflammatory processes. Type II diabetes is characterized by a combination of defects in insulin secretion and action. Nitric oxide (NO) has been implicated in $\beta$-cell failure in type I diabetes. NO is produced by inflammatory cytokines, such as interleukin-1 $\beta$
$(\mathrm{IL}-1 \beta)$, tumor necrosis factor- $\alpha$ (TNF- $\alpha)$ and interferon- $\gamma$ $(\mathrm{IFN}-\gamma){ }^{79}$ The $\beta$-cell is known to be highly susceptible to NO. It can induce DNA damage, and leads to necrosis or apoptosis through the poly (ADP-ribose) polymerase (PARP) pathway or the p53 pathway, respectively (Figure 4a). However, the different susceptibility of various cell types toward NO cannot be explained by DNA damage. Studies on islet cells lacking PARP and p53-negative cells suggested an apoptosis pathway distinct from the DNA damage pathway. ${ }^{80,81}$ We found that NO causes ER stress by depleting ER $\mathrm{Ca}^{2+}$ stores and leads to apoptosis in $\beta$-cells via CHOP induction (Figure 4a). ${ }^{56}$ Maintenance of $\mathrm{Ca}^{2+}$ homeostasis in the ER is essential for protein folding. Molecular components
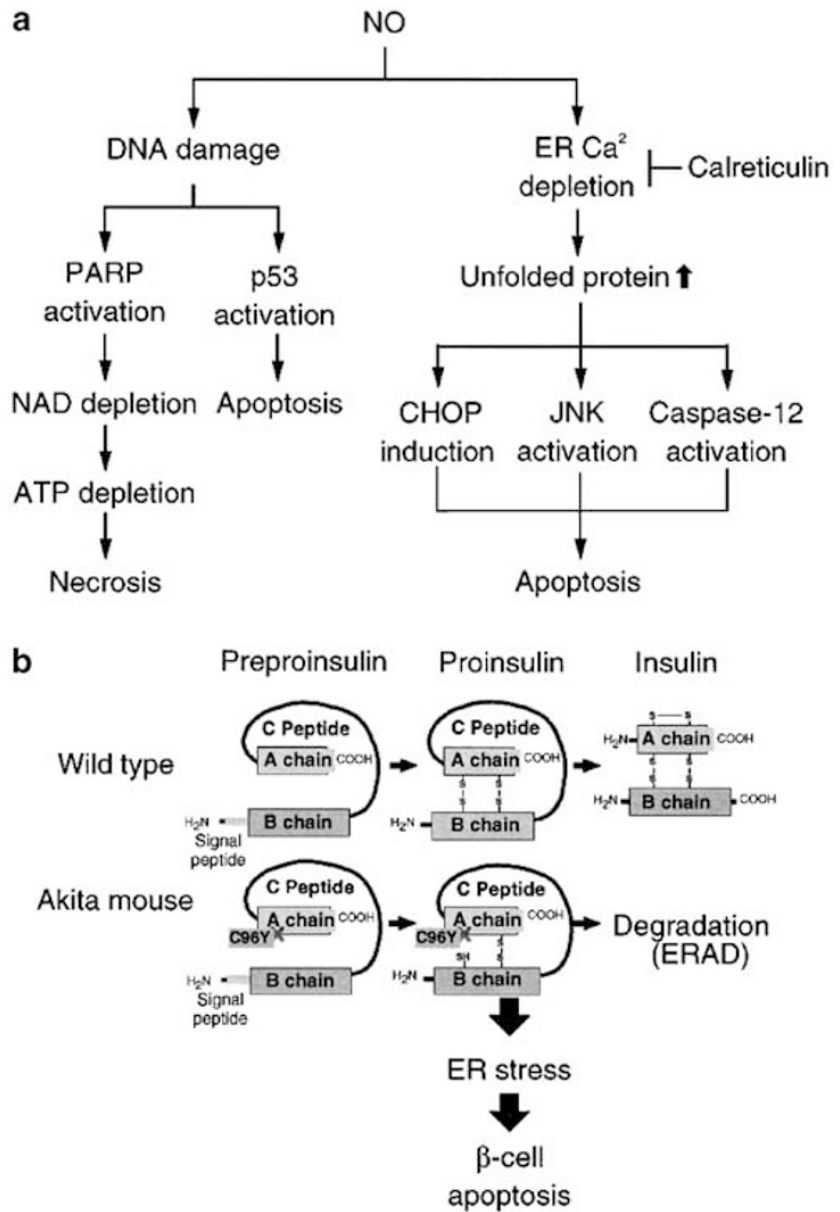

Figure 4 (a) Pathways of NO-induced cell death. Excessive NO leads to cell death through DNA damage or ER stress. DNA damage causes cell death via the apoptosis pathway mediated by activation of $p 53$ or via the necrosis pathway mediated by activation of PARP, which results in depletion of NAD ${ }^{+}$and ATP. While high amounts of NO cause DNA damage, lower amounts of NO cause ER stress without DNA damage in some cell types such as pancreatic $\beta$-cell, which has developed ER. NO depletes $\mathrm{ER} \mathrm{Ca}{ }^{2+}$, which results in accumulation of unfolded proteins in the ER, and leads to apoptosis via induction of $\mathrm{CHOP}$ and activation of JNK and caspase-12. (b) Mechanism of ER stress-mediated $\beta$-cell apoptosis in Akita mouse. In wild-type mouse, preproinsulin is processed to proinsulin by cleavage of signal peptide and by formation of disulfide bonds between (a) and (b) chains in the ER. In Akita mouse, a missense mutation (Cys96Tyr) in the insulin 2 gene disrupts a disulfide bond and induces a drastic conformational change of this molecule. Mutant insulin may be degraded by the ERAD pathway, causes ER stress in $\beta$-cells and leads to apoptosis 
of $\mathrm{ER} \mathrm{Ca}^{2+}$ homeostasis consist of pumps for $\mathrm{Ca}^{2+}$ uptake (SERCAs), $\mathrm{Ca}^{2+}$-binding proteins and channels for $\mathrm{Ca}^{2+}$ release, including inositol 1,4,5-triphosphate receptors and ryanodine receptors. NO was reported to activate ryanodine receptors or to inhibit SERCA activity by protein nitration. ${ }^{82-84}$ Overexpression of calreticulin, which is a major $\mathrm{Ca}^{2+}$-binding protein in the ER, prevents $\beta$-cells from NO-mediated apoptosis. ${ }^{56}$ It should be noted that the expression of SERCA2b and calreticulin is induced by ER stress, which means that increased $\mathrm{ER} \mathrm{Ca}^{2+}$ stores are likely to be required to adapt ER stress conditions. Furthermore, DNA microarray analysis showed that $\mathrm{CHOP}$ is induced by IL- $1 \beta$ plus IFN- $\gamma$ in primary rat $\beta$-cells. ${ }^{85}$

In type II diabetes, impaired insulin action, which is often associated with obesity and physical inactivity, is a major factor in progression of the disease, but hyperglycemia occurs only when $\beta$-cells fail to compensate for the increased demand for insulin secretion. Overload of $\beta$-cells in conditions such as hyperglycemia, obesity and long-term treatment with sulfonylureas leads to $\beta$-cell dysfunction and to apoptosis through a process referred as ' $\beta$-cell exhaustion'. We hypothesized that an imbalance between the demand for insulin secretion and the secretion capacity of $\beta$-cells causes ER stress and leads to apoptosis. We addressed this hypothesis using the Akita diabetic mouse which has a mutation in the insulin 2 gene (Ins2) (Cys96Tyr), and is characterized by progressive hyperglycemia with reduced $\beta$ cell mass but without insulitis or obesity. ${ }^{86-88}$ This mutation disrupts a disulfide bond in proinsulin between the $A$ and $B$ chains, and is expected to induce a drastic conformational change of this molecule (Figure 4b). Mutant insulin is not secreted and is presumably degraded. However, the phenotype of Akita mouse is not only due to the loss of insulin, but rather due to gain of function, because single Ins1 or Ins2 knockout mice do not develop diabetes. ${ }^{89}$ We found that disruption of the CHOP gene markedly delayed the onset of disease in heterozygous Akita mice. ${ }^{59}$ This indicates that progressive hyperglycemia in Akita mice is caused by $\beta$-cell apoptosis through CHOP induction. Since disruption of the CHOP gene cannot delay the onset of disease in homozygous Akita mice, it is obvious that other pathway(s) are involved in this process. However, our results suggest that the block of at least one of the apoptosis pathways can modulate the development of disease. Although the Ins2 ${ }^{\mathrm{C} 96 \mathrm{Y}}$ mutation was only identified in the mouse, other mutation(s) may cause diabetes through ER stress-mediated apoptosis. It is tempting to speculate that a long-term and low-level ER stress causes apoptosis in $\beta$-cells via CHOP and leads to diabetes.

\section{Brain ischemia}

Depletion of glucose, oxygen and $\mathrm{ER} \mathrm{Ca}^{2+}$, which is a characteristic feature of tissue ischemia, is strongly associated with ER stress. Protein aggregation in the ER after focal brain ischemia and reperfusion was observed using electron microscopy analysis. ${ }^{90}$ These aggregates persist in vulnerable neurons but not in resistant ones. Global translational attenuation, a key response in the pathogenesis of neuronal cell injury, is caused by phosphorylation of elF $2 \alpha$ via the activation of PERK. ${ }^{91}$ These findings strongly suggest that ER stress is induced by brain ischemia and reperfusion. Induction of CHOP mRNA was observed in the rat hippocampus subjected to global cerebral ischemia. ${ }^{92,93}$ NO has been implicated in the pathophysiology of brain ischemia. NO causes the depletion of ER $\mathrm{Ca}^{2+}$ and induces CHOP mRNA in primary neuronal cultures as well as in pancreatic $\beta$ cells. ${ }^{56,94}$ Consistent with this result, pretreatment with an NO synthase inhibitor could restore $\mathrm{ER} \mathrm{Ca}^{2+}$ after brain ischemia, and mice lacking the inducible NO synthase gene had a decreased susceptibility to ischemia. ${ }^{95,96}$ Furthermore, we recently found that $\mathrm{CHOP}^{-/-}$mice have smaller infarcts than wild-type animals subjected to bilateral carotid artery occlusion. ${ }^{96 a}$ Since acute neuronal cell death in the ischemic core region is mostly due to necrosis, we speculate that ER stress-mediated apoptosis in vulnerable neurons contributes to delayed cell death or to neurodegeneration in the penumbra of focal ischemia. CHOP can be an important target for therapeutic intervention to prevent secondary progression of ischemic brain injuries.

\section{Neurodegenerative disease}

Neurodegenerative diseases have an underlying similarity in progressive neuronal dysfunction and neuronal cell death. Protein misfolding has been implicated in the pathogenesis, for example, the accumulation of misfolded proteins such as $\beta$-amyloid, $\alpha$-synuclein and huntingtin is apparently associated with selective neuronal cell death in Alzheimer's, Parkinson's and Huntington's diseases, respectively. Mutations in presenilin-1, which increase the production of $\beta$ amyloid, were shown to increase CHOP protein, using presenilin-1 mutant knockin mice. ${ }^{97}$ Increased CHOP was suggested to contribute to the pathogenesis of presenilin-1 mutations by sensitizing neuronal cells to apoptosis. ${ }^{97}$ However, concerning the role of presenilin-1 in the ER stress pathway, the question of whether or not presenilin-1 mutations downregulate induction of $\mathrm{BiP}$ and $\mathrm{CHOP}$ is still being debated. ${ }^{98,99}$ Therefore, it remains to be studied whether CHOP induction and ER stress-mediated apoptosis occur in the development of Alzheimer's disease. Several studies indicate that oxidative damages may have an important role in the development of Parkinson's disease. Recent studies using serial analysis of gene expression (SAGE) and DNA microarray analysis revealed that genes involved in ER stress including the CHOP gene are induced by a Parkinsonisminducing neurotoxin 6-hydroxydopamine, which forms free radicals. ${ }^{100,101}$ Since NO plays an important role in dopaminergic neurodegeneration induced by another dopaminergic neurodegeneration neurotoxin 1-methyl-4-phenyl-1,2,3,6-tetrahydropyridine (MPTP), it is worth determining if disruption of the CHOP gene prevents neuronal cells from MPTP-induced apoptosis. ${ }^{102}$ Several lines of evidence suggested a link between dysfunction of the ERAD system and the pathogenesis of Parkinson's and polyglutamine disease. Mutation of parkin, that is an E3 ubiquitin ligase, is one of the major causes of familial Parkinson's disease. ${ }^{103}$ Parkin is induced by ER stress, and overexpression of parkin confers resistance to both ER stress and mutant $\alpha$-synuclein-induced toxicity. ${ }^{104,105}$ Furthermore, accumulation of polyglutamine-containing proteins was found to cause ER stress, presumably due to 
saturation of the cytosolic protein degradation system. ${ }^{19}$ These findings suggest that mutations in the parkin gene or expression of pathogenic polyglutamine proteins in neurons inhibit degradation of misfolded proteins, cause ER stress and lead to ER stress-mediated apoptosis. Therefore, CHOPmediated apoptosis may also be involved in the development of Parkinson's disease and polyglutamine disease.

\section{Concluding Remarks}

Since the discovery of ER stress in the late 1980s, knowledge of how ER can sense stress and respond to it has accumulated. The importance of ER stress response in human health and disease is now widely accepted. On the other hand, research on ER stress-induced apoptosis has just begun. $\mathrm{CHOP}$ is the first identified protein that mediates $\mathrm{ER}$ stress-induced apoptosis and much is known on the roles of this molecule in apoptosis. Nevertheless, it remains little known how CHOP induces apoptosis.

Since induction of CHOP is involved in the development of various diseases, CHOP-targeted therapies may be useful for these diseases. For instance, suppression of CHOP by RNA interference, decoy oligodeoxynucleotides or drug inhibitors could have a significant therapeutic potential to modulate type I diabetes, brain ischemia and others. On the other hand, overexpression of CHOP may represent a new class of anticancer therapy. Since induction of $\mathrm{BiP}$ has been observed in a variety of tumor cells, overexpression of $\mathrm{CHOP}$ directed by the BiP promoter may be used as a highly specific therapy for cancer. Further studies on CHOP-mediated apoptosis will provide a basis for new therapeutic approaches to diseases associated with ER stress.

\section{Acknowledgements}

We thank M Ohara (Fukuoka, Japan) for comments on the manuscript, and $Y$ Indo for secretarial assistance. This work was supported in part by a Grant-in-Aid (14037257 to MM) from the Ministry of Education, Science, Technology, Sports and Culture of Japan. S Oyadomari was supported by a fellowship from the Naito Foundation.

\section{References}

1. Kopito RR (2000) Aggresomes, inclusion bodies and protein aggregation Trends. Cell Biol. 10: 524-530

2. Kaufman RJ (1999) Stress signaling from the lumen of the endoplasmic reticulum: coordination of gene transcriptional and translational controls. Genes Dev. 13: 1211-1233

3. Mori K (2000) Tripartite management of unfolded proteins in the endoplasmic reticulum. Cell 101: 451-454

4. Ron D (2002) Translational control in the endoplasmic reticulum stress response. J. Clin. Invest. 110: 1383-1388

5. Kaufman RJ (2002) Orchestrating the unfolded protein response in health and disease. J. Clin. Invest. 110: 1389-1398

6. Harding HP, Calfon M, Urano F, Novoa I and Ron D (2002) Transcriptional and translational control in the mammalian unfolded protein response. Annu. Rev. Cell Dev. Biol. 18: 575-599

7. Kozutsumi MY, Segal M, Normington K, Gething MJ and Sambrook J (1988) The presence of malfolded proteins in the endoplasmic reticulum signals the induction of glucose-regulated proteins. Nature 332: 462-464
8. Yoshida H, Haze K, Yanagi H, Yura T and Mori K (1998) Identification of the cis-acting endoplasmic reticulum stress response element responsible for transcriptional induction of mammalian glucose-regulated proteins. Involvement of basic leucine zipper transcription factors. J. Biol. Chem. 273: 33741-33749

9. Caspersen C, Pedersen PS and Treiman M (2000) The sarco/endoplasmic reticulum calcium-ATPase $2 b$ is an endoplasmic reticulum stress-inducible protein. J. Biol. Chem. 275: 22363-22372

10. Harding HP, Zhang Y, Zeng H, Novoa I, Lu PD, Calfon M, Sadri N, Yun C, Popko B, Paules R, Stojdl DF, Bell JC, Hettmann T and Leiden JM (2003) An integrated stress response regulates amino acid metabolism and resistance to oxidative stress. Mol. Cell 11: 619-633

11. Kopito RR (1997) ER quality control: the cytoplasmic connection. Cell 88: $427-430$

12. Travers KJ, Patil CK, Wodicka L, Lockhart DJ, Weissman JS and Walter $P$ (2000) Functional and genomic analyses reveal an essential coordination between the unfolded protein response and ER-associated degradation. Cell 101: 249-258

13. Yoshida H, Matsui T, Hosokawa N, Kaufman RJ, Nagata K and Mori K (2003) A time-dependent phase shift in the mammalian unfolded protein response. Dev. Cell 4: 265-271

14. Pahl HL, Sester M, Burgert HG and Baeuerle PA (1996) Activation of transcription factor NF-kappaB by the adenovirus $\mathrm{E} 3 / 19 \mathrm{~K}$ protein requires its ER retention. J. Cell Biol. 132: 511-522

15. Jiang HY, Wek SA, McGrath BC, Scheuner D, Kaufman RJ, Cavener DR and Wek RC (2003) Phosphorylation of the alpha subunit of eukaryotic initiation factor 2 is required for activation of NF-kappaB in response to diverse cellular stresses. Mol. Cell. Biol. 23: 5651-5663

16. Ferri KF and Kroemer G (2001) Organelle-specific initiation of cell death pathways. Nat. Cell Biol. 3: E255-E263

17. Oyadomari S, Araki E and Mori M (2002) Endoplasmic reticulum stressmediated apoptosis in pancreatic beta-cells. Apoptosis 7: 335-345

18. Urano F, Wang X, Bertolotti A, Zhang Y, Chung P, Harding HP and Ron D (2000) Coupling of stress in the ER to activation of JNK protein kinases by transmembrane protein kinase IRE1. Science 287: 664-666

19. Nishitoh H, Matsuzawa A, Tobiume K, Saegusa K, Takeda K, Inoue K, Hori S, Kakizuka A and Ichijo H (2002) ASK1 is essential for endoplasmic reticulum stress-induced neuronal cell death triggered by expanded polyglutamine repeats. Genes Dev. 16: 1345-1355

20. Nakagawa T, Zhu H, Morishima N, Li E, Xu J, Yankner BA and Yuan J (2000) Caspase-12 mediates endoplasmic-reticulum-specific apoptosis and cytotoxicity by amyloid-beta. Nature 403: 98-103

21. Fischer $\mathrm{H}$, Koenig U, Eckhart L and Tschachler E (2002) Human caspase 12 has acquired deleterious mutations. Biochem. Biophys. Res. Commun. 293: $722-726$

22. Wei MC, Zong WX, Cheng EH, Lindsten T, Panoutsakopoulou V, Ross AJ, Roth KA, MacGregor GR, Thompson CB and Korsmeyer SJ (2001) Proapoptotic BAX and BAK: a requisite gateway to mitochondrial dysfunction and death. Science 292: 727-730

23. Matsumoto M, Minami M, Takeda K, Sakao Y and Akira S (1996) Ectopic expression of CHOP (GADD153) induces apoptosis in M1 myeloblastic leukemia cells. FEBS Lett. 395: 143-147

24. Ron D and Habener JF (1992) CHOP, a novel developmentally regulated nuclear protein that dimerizes with transcription factors C/EBP and LAP and functions as a dominant-negative inhibitor of gene transcription. Genes Dev. 6: 439-453

25. Ubeda M, Wang XZ, Zinszner H, Wu I, Habener JF and Ron D (1996) Stressinduced binding of the transcriptional factor $\mathrm{CHOP}$ to a novel DNA control element. Mol. Cell. Biol. 16: 1479-1489

26. Wang XZ and Ron D (1996) Stress-induced phosphorylation and activation of the transcription factor CHOP (GADD153) by p38 MAP kinase. Science 272 : 1347-1349

27. Maytin EV, Ubeda M, Lin JC and Habener JF (2001) Stress-inducible transcription factor $\mathrm{CHOP} /$ gadd 153 induces apoptosis in mammalian cells via p38 kinase-dependent and -independent mechanisms. Exp. Cell Res. 267: 193-204

28. Barone MV, Crozat A, Tabaee A, Philipson L and Ron D (1994) CHOP (GADD153) and its oncogenic variant, TLS-CHOP, have opposing effects on the induction of G1/S arrest. Genes Dev. 8: 453-464 
29. Ubeda M, Vallejo M and Habener JF (1999) CHOP enhancement of gene transcription by interactions with Jun/Fos AP-1 complex proteins. Mol. Cell. Biol. 19: 7589-7599

30. Fornace Jr AJ, Alamo Jr I and Hollander MC (1988) DNA damage-inducible transcripts in mammalian cells. Proc. Natl. Acad. Sci. USA 85: 8800-8804

31. Wang XZ, Lawson B, Brewer JW, Zinszner H, Sanjay A, Mi LJ, Boorstein R Kreibich G, Hendershot LM and Ron D (1996) Signals from the stressed endoplasmic reticulum induce $\mathrm{C} / \mathrm{EBP}$-homologous protein (CHOP) GADD153). Mol. Cell. Biol. 16: 4273-4280

32. Okada T, Yoshida H, Akazawa R, Negishi M and Mori K (2002) Distinct roles of activating transcription factor 6 (ATF6) and double-stranded RNA-activated protein kinase-like endoplasmic reticulum kinase (PERK) in transcription during the mammalian unfolded protein response. Biochem. J. 366: 585-594

33. Bertolotti A, Zhang Y, Hendershot LM, Harding HP and Ron D (2000) Dynamic interaction of BiP and ER stress transducers in the unfolded-protein response. Nat. Cell Biol. 2: 326-332

34. Sommer T and Jarosch E (2002) BiP binding keeps ATF6 at bay. Dev. Cell 3 : 1-2

35. Ye J, Rawson RB, Komuro R, Chen X, Dave UP, Prywes R, Brown MS and Goldstein JL (2000) ER stress induces cleavage of membrane-bound ATF6 by the same proteases that process SREBPs. Mol. Cell 6: 1355-1364

36. Yoshida H, Okada T, Haze K, Yanagi H, Yura T, Negishi M and Mori K (2000) ATF6 activated by proteolysis binds in the presence of NF-Y (CBF) directly to the cis-acting element responsible for the mammalian unfolded protein response. Mol. Cell. Biol. 20: 6755-6767

37. Yoshida H, Okada T, Haze K, Yanagi H, Yura T, Negishi M and Mori K (2001) Endoplasmic reticulum stress-induced formation of transcription factor complex ERSF including NF-Y (CBF) and activating transcription factors 6 alpha and 6beta that activates the mammalian unfolded protein response. Mol. Cell. Biol. 21: 1239-1248

38. Yoshida H, Matsui T, Yamamoto A, Okada T and Mori K (2001) XBP1 mRNA is induced by ATF6 and spliced by IRE1 in response to ER stress to produce a highly active transcription factor. Cell 107: 881-891

39. Calfon M, Zeng H, Urano F, Till JH, Hubbard SR, Harding HP, Clark SG and Ron D (2002) IRE1 couples endoplasmic reticulum load to secretory capacity by processing the XBP-1 mRNA. Nature 415: 92-96

40. Lee K, Tirasophon W, Shen X, Michalak M, Prywes R, Okada T, Yoshida H, Mori $\mathrm{K}$ and Kaufman RJ (2002) IRE1-mediated unconventional mRNA splicing and S2P-mediated ATF6 cleavage merge to regulate XBP1 in signaling the unfolded protein response. Genes Dev. 16: 452-466

41. Wang Y, Shen J, Arenzana N, Tirasophon W, Kaufman RJ and Prywes R (2000) Activation of ATF6 and an ATF6 DNA binding site by the endoplasmic reticulum stress response. J. Biol. Chem. 275: 27013-27020

42. Ubeda M and Habener JF (2000) CHOP gene expression in response to endoplasmic-reticular stress requires NFY interaction with different domains of a conserved DNA-binding element. Nucleic Acids Res. 28: 4987-4997

43. Roy B and Lee AS (1999) The mammalian endoplasmic reticulum stress response element consists of an evolutionarily conserved tripartite structure and interacts with a novel stress-inducible complex. Nucleic Acids Res. 27 1437-1443

44. Bruhat $A$, Jousse $C$, Carraro V, Reimold $A M$, Ferrara $M$ and Fafournoux $P$ (2000) Amino acids control mammalian gene transcription: activating transcription factor 2 is essential for the amino acid responsiveness of the CHOP promoter. Mol. Cell. Biol. 20: 7192-7204

45. Scheuner D, Song B, McEwen E, Liu C, Laybutt R, Gillespie P, Saunders T, Bonner-Weir S and Kaufman RJ (2001) Translational control is required for the unfolded protein response and in vivo glucose homeostasis. Mol. Cell 7 1165-1176

46. Harding HP, Novoa II, Zhang Y, Zeng H, Wek R, Schapira M and Ron D (2000) Regulated translation initiation controls stress-induced gene expression in mammalian cells. Mol. Cell 6: 1099-1108

47. Chen BP, Wolfgang CD and Hai T (1996) Analysis of ATF3, a transcription factor induced by physiological stresses and modulated by gadd153/Chop10. Mol. Cell. Biol. 16: 1157-1168

48. Wolfgang CD, Chen BP, Martindale JL, Holbrook NJ and Hai T (1997) gadd153/Chop10, a potential target gene of the transcriptional repressor ATF3. Mol. Cell. Biol. 17: 6700-6707

49. Fawcett TW, Martindale JL, Guyton KZ, Hai T and Holbrook NJ (1999) Complexes containing activating transcription factor (ATF)/cAMP-responsive- element-binding protein (CREB) interact with the CCAAT/enhancer-binding protein (C/EBP)-ATF composite site to regulate Gadd153 expression during the stress response. Biochem. J. 339: 135-141

50. Estes SD, Stoler DL and Anderson GR (1995) Normal fibroblasts induce the C/EBP beta and ATF-4 bZIP transcription factors in response to anoxia. Exp. Cell Res. 220: 47-54

51. Bartlett JD, Luethy JD, Carlson SG, Sollott SJ and Holbrook NJ (1992) Calcium ionophore A23187 induces expression of the growth arrest and DNA damage inducible CCAAT/enhancer-binding protein (C/EBP)-related gene, gadd153. $\mathrm{Ca}^{2+}$ increases transcriptional activity and mRNA stability. J. Biol. Chem. 267: 20465-20470

52. Bruhat A, Jousse C, Wang XZ, Ron D, Ferrara M and Fafournoux $P$ (1997) Amino acid limitation induces expression of CHOP, a CCAAT/enhancer binding protein-related gene, at both transcriptional and post-transcriptional levels. J. Biol. Chem. 272: 17588-17593

53. Schmitt-Ney M and Habener JF (2000) CHOP/GADD153 gene expression response to cellular stresses inhibited by prior exposure to ultraviolet light wavelength band C (UVC). Inhibitory sequence mediating the UVC response localized to exon 1. J. Biol. Chem. 275: 40839-40845

54. Jousse $C$, Bruhat $A$, Carraro V, Urano F, Ferrara M, Ron D and Fafournoux $P$ (2001) Inhibition of CHOP translation by a peptide encoded by an open reading frame localized in the chop 5'UTR. Nucleic Acids Res. 29: 4341-4351

55. Tobiume K, Matsuzawa A, Takahashi T, Nishitoh H, Morita K, Takeda K, Minowa O, Miyazono K, Noda T and Ichijo H (2001) ASK1 is required for sustained activations of JNK/p38 MAP kinases and apoptosis. EMBO Rep. 2: 222-228

56. Oyadomari S, Takeda K, Takiguchi M, Gotoh T, Matsumoto M, Wada I, Akira S, Araki E and Mori M (2001) Nitric oxide-induced apoptosis in pancreatic beta cells is mediated by the endoplasmic reticulum stress pathway. Proc. Natl. Acad. Sci. USA 98: 10845-10850

57. Gotoh T, Oyadomari S Mori K and Mori M (2002) Nitric oxide-induced apoptosis in RAW 264.7 macrophages is mediated by endoplasmic reticulum stress pathway involving ATF6 and CHOP. J. Biol. Chem. 277: 12343-12350

58. Zinszner H, Kuroda M, Wang X, Batchvarova N, Lightfoot RT, Remotti H, Stevens JL and Ron D (1998) CHOP is implicated in programmed cell death in response to impaired function of the endoplasmic reticulum. Genes Dev. 12 982-995

59. Oyadomari S, Koizumi A, Takeda K, Gotoh T, Akira S, Araki E and Mori M (2002) Targeted disruption of the Chop gene delays endoplasmic reticulum stress-mediated diabetes. J. Clin. Invest. 109: 525-532

60. Wang XZ, Kuroda M, Sok J, Batchvarova N, Kimmel R, Chung P, Zinszner H and Ron D (1998) Identification of novel stress-induced genes downstream of chop. EMBO J. 17: 3619-3630

61. Sok J, Wang XZ, Batchvarova N, Kuroda M, Harding H and Ron D (1999) CHOP-dependent stress-inducible expression of a novel form of carbonic anhydrase VI. Mol. Cell. Biol. 19: 495-504

62. McCullough KD, Martindale JL, Klotz LO, Aw TY and Holbrook NJ (2001) Gadd153 sensitizes cells to endoplasmic reticulum stress by down-regulating Bcl2 and perturbing the cellular redox state. Mol. Cell. Biol. 21: 1249-1259

63. Gotoh T, Takeda K, Oyadomari S and Mori M. hsp70-DnaJ chaperone pair prevents nitric oxide-, $\mathrm{CHOP}$-induced apoptosis by inhibiting translocation of Bax to mitochondria. Cell Death Differ. in press

64. Wang H, lakova P, Wilde M, Welm A, Goode T, Roesler WJ and Timchenko NA (2001) C/EBPalpha arrests cell proliferation through direct inhibition of Cdk2 and Cdk4. Mol. Cell 8: 817-828

65. Wang H, Goode T, lakova P, Albrecht JH and Timchenko NA (2002) C/ EBPalpha triggers proteasome-dependent degradation of cdk4 during growth arrest. EMBO J. 21: 930-941

66. Kawai T, Matsumoto M, Takeda K, Sanjo H and Akira S (1998) ZIP kinase, a novel serine/threonine kinase which mediates apoptosis. Mol. Cell. Biol. 18: 1642-1651

67. Reimold AM, Etkin A, Clauss I, Perkins A, Friend DS, Zhang J, Horton HF, Scott A, Orkin SH, Byrne MC, Grusby MJ and Glimcher LH (2000) An essential role in liver development for transcription factor XBP-1. Genes Dev. 14: 152-157

68. Harding HP, Zeng $H$, Zhang $Y$, Jungries $R$, Chung $P$, Plesken $H$, Sabatini DD and Ron D (2001) Diabetes mellitus and exocrine pancreatic dysfunction in perk-/- mice reveals a role for translational control in secretory cell survival. Mol. Cell 7: 1153-1163 
69. Zhang P, McGrath B, Li S, Frank A, Zambito F, Reinert J, Gannon M, Ma K, McNaughton K and Cavener DR (2002) The PERK eukaryotic initiation factor 2 alpha kinase is required for the development of the skeletal system, postnatal growth, and the function and viability of the pancreas. Mol. Cell. Biol. 22: 3864-3874

70. Reimold AM, Iwakoshi NN, Manis J, Vallabhajosyula P, Szomolanyi-Tsuda E, Gravallese EM, Friend D, Grusby MJ, Alt F and Glimcher LH (2001) Plasma cell differentiation requires the transcription factor XBP-1. Nature 412: 300307

71. Harding HP, Zhang Y, Bertolotti A, Zeng H and Ron D (2000) Perk is essential for translational regulation and cell survival during the unfolded protein response. Mol. Cell 5: 897-904

72. Coutts M, Cui K, Davis KL, Keutzer JC and Sytkowski AJ (1999) Regulated expression and functional role of the transcription factor $\mathrm{CHOP}$ (GADD153) in erythroid growth and differentiation. Blood 93: 3369-3378

73. Maytin EV and Habener JF (1998) Transcription factors C/EBP alpha, C/EBP beta, and CHOP (Gadd153) expressed during the differentiation program of keratinocytes in vitro and in vivo. J. Invest. Dermatol. 110: 238-246

74. Mathis D, Vence L and Benoist C (2001) Beta-cell death during progression to diabetes. Nature 414: 792-798

75. Kaufman RJ, Scheuner D, Schroder M, Shen X, Lee K, Liu CY and Arnold SM (2002) The unfolded protein response in nutrient sensing and differentiation. Nat. Rev. Mol. Cell. Biol. 3: 411-421

76. Harding HP and Ron D (2002) Endoplasmic reticulum stress and the development of diabetes: a review. Diabetes 51 (Suppl 3): S455-S461

77. Araki E, Oyadomari S and Mori M (2003) Endoplasmic reticulum stress and diabetes mellitus. Intern. Med. 42: 7-14

78. Thornton C (1997) Autopsy findings in the Wolcott-Rallison syndrome Pediatr. Pathol. Lab. Med. 17: 487-496

79. Nicolino M, Delepine M, Barrett T, Golamaully M, Lathrop GM and Julier C (2000) EIF2AK3, encoding translation initiation factor 2-alpha kinase 3, is mutated in patients with Wolcott-Rallison syndrome. Nat. Genet. 25: 406-409

80. Eizirik DL and Mandrup-Poulsen T (2001) A choice of death - the signaltransduction of immune-mediated beta-cell apoptosis. Diabetologia 44: 21152133

81. Heller B, Wang ZQ, Wagner EF, Radons J, Burkle A, Fehsel K, Burkart V and Kolb H (1995) Inactivation of the poly(ADP-ribose) polymerase gene affects oxygen radical and nitric oxide toxicity in islet cells. J. Biol. Chem. 270: 1117611180

82. Messmer UK and Brune B (1996) Nitric oxide-induced apoptosis: p53dependent and p53-independent signalling pathways. Biochem. J. 319: 299305

83. Viner RI, Ferrington DA, Williams TD, Bigelow DJ and Schoneich C (1999) Protein modification during biological aging: selective tyrosine nitration of the SERCA2a isoform of the sarcoplasmic reticulum Ca2+-ATPase in skeletal muscle. Biochem. J. 340: 657-669

84. Xu KY, Huso DL, Dawson TM, Bredt DS and Becker LC (1999) Nitric oxide synthase in cardiac sarcoplasmic reticulum. Proc. Natl. Acad. Sci. USA 96: 657-662

85. Xu L, Eu JP, Meissner G and Stamler JS (1998) Activation of the cardiac calcium release channel (ryanodine receptor) by poly-S-nitrosylation. Science 279: 234-237

86. Cardozo AK, Kruhoffer M, Leeman R, Orntoft T and Eizirik DL (2001) Identification of novel cytokine-induced genes in pancreatic beta-cells by highdensity oligonucleotide arrays. Diabetes 50: 909-920

87. Yoshioka M, Kayo T, Ikeda T and Koizumi A (1997) A novel locus, Mody4, distal to D7Mit189 on chromosome 7 determines early-onset NIDDM in nonobese C57BL/6 (Akita) mutant mice. Diabetes 46: 887-894

88. Kayo T and Koizumi A (1998) Mapping of murine diabetogenic gene mody on chromosome 7 at D7Mit258 and its involvement in pancreatic islet and beta cell development during the perinatal period. J. Clin. Invest. 101: 2112-2118

89. Wang J, Takeuchi T, Tanaka S, Kubo SK, Kayo T, Lu D, Takata K, Koizumi A and Izumi T (1999) A mutation in the insulin 2 gene induces diabetes with severe pancreatic beta-cell dysfunction in the Mody mouse. J. Clin. Invest. 103: $27-37$

90. Leroux L, Desbois P, Lamotte L, Duvillie B, Cordonnier N, Jackerott M, Jami J, Bucchini D and Joshi RL (2001) Compensatory responses in mice carrying a null mutation for Ins1 or Ins2. Diabetes 50 (Suppl 1): S150-S153

91. Hu BR, Janelidze S, Ginsberg MD, Busto R, Perez-Pinzon M, Sick TJ, Siesjo BK and Liu CL (2001) Protein aggregation after focal brain ischemia and reperfusion. J. Cereb. Blood Flow Metab. 21: 865-875

92. Kumar R, Azam S, Sullivan JM, Owen C, Cavener DR, Zhang P, Ron D, Harding HP, Chen JJ, Han A, White BC, Krause GS and DeGracia DJ (2001) Brain ischemia and reperfusion activates the eukaryotic initiation factor 2 alpha kinase, PERK. J. Neurochem. 77: 1418-1421

93. Paschen W, Gissel C, Linden T, Althausen S and Doutheil J (1998) Activation of gadd153 expression through transient cerebral ischemia: evidence that ischemia causes endoplasmic reticulum dysfunction. Brain Res. Mol. Brain Res. 60: 115-122

94. Jin K, Mao XO, Eshoo MW, Nagayama T, Minami M, Simon RP and Greenberg DA (2001) Microarray analysis of hippocampal gene expression in global cerebral ischemia. Ann. Neurol. 50: 93-103

95. Doutheil J, Althausen S, Treiman M and Paschen W (2000) Effect of nitric oxide on endoplasmic reticulum calcium homeostasis, protein synthesis and energy metabolism. Cell Calcium 27: 107-115

96. Kohno K, Higuchi T, Ohta S, Kumon Y and Sakaki S (1997) Neuroprotective nitric oxide synthase inhibitor reduces intracellular calcium accumulation following transient global ischemia in the gerbil. Neurosci. Lett. 224: 17-20

97. Iadecola C, Zhang F, Casey R, Nagayama M and Ross ME (1997) Delayed reduction of ischemic brain injury and neurological deficits in mice lacking the inducible nitric oxide synthase gene. J. Neurosci. 17: 9157-9164

98. Tajiri S, Oyadomari S, Yano S, Morioka M, Gotoh T, Hamada J-I, Ushio Y and Mori M. Ischemia-induced neuronal cell death is mediated by the endoplasmic reticulum stress pathway involving CHOP. Cell Death Differ in press

99. Milhavet O, Martindale JL, Camandola S, Chan SL, Gary DS, Cheng A, Holbrook NJ and Mattson MP (2002) Involvement of Gadd153 in the pathogenic action of presenilin-1 mutations. J. Neurochem. 83: 673-681

100. Katayama T, Imaizumi K, Sato N, Miyoshi K, Kudo T, Hitomi J, Morihara T, Yoneda T, Gomi F, Mori Y, Nakano Y, Takeda J, Tsuda T, Itoyama $Y$, Murayama O, Takashima A, St George-Hyslop P, Takeda M and Tohyama M (1999) Presenilin-1 mutations downregulate the signalling pathway of the unfolded-protein response. Nat. Cell Biol. 1: 479-485

101. Sato N, Urano F, Yoon Leem J, Kim SH, Li M, Donoviel D, Bernstein A, Lee AS, Ron D, Veselits ML, Sisodia SS and Thinakaran G (2000) Upregulation of $\mathrm{BiP}$ and $\mathrm{CHOP}$ by the unfolded-protein response is independent of presenilin expression. Nat. Cell Biol. 2: 863-870

102. Ryu EJ, Harding HP, Angelastro JM, Vitolo OV, Ron D and Greene LA (2002) Endoplasmic reticulum stress and the unfolded protein response in cellular models of Parkinson's disease. J. Neurosci. 22: 10690-10698

103. Holtz WA and O'Malley KL (2003) Parkinsonian mimetics induce aspects of unfolded protein response in death of dopaminergic neurons. J. Biol. Chem. 278: 19367-19377

104. Liberatore GT, Jackson-Lewis V, Vukosavic S, Mandir AS, Vila M, McAuliffe WG, Dawson VL, Dawson TM and Przedborski S (1999) Inducible nitric oxide synthase stimulates dopaminergic neurodegeneration in the MPTP model of Parkinson disease. Nat. Med. 5: 1403-1409

105. Shimura H, Hattori N, Kubo S, Mizuno Y, Asakawa S, Minoshima S, Shimizu N, Iwai K, Chiba T, Tanaka K and Suzuki T (2000) Familial Parkinson disease gene product, parkin, is a ubiquitin-protein ligase. Nat. Genet. 25: 302-305

106. Imai $Y$, Soda $M$ and Takahashi $R$ (2000) Parkin suppresses unfolded protein stress-induced cell death through its E3 ubiquitin-protein ligase activity. J. Biol. Chem. 275: 35661-35664

107. Petrucelli L, O'Farrell C, Lockhart PJ, Baptista M, Kehoe K, Vink L, Choi P, Wolozin B, Farrer M, Hardy J and Cookson MR (2002) Parkin protects against the toxicity associated with mutant alpha-synuclein: proteasome dysfunction selectively affects catecholaminergic neurons. Neuron 36: 1007-1019 